\section{大阪産業大学土木工学科 土木計画学研究室}

\section{棉原 和彦 \\ 大島 秀樹 \\ 福井 義員}

はじめに

わが大阪産業大学は, 生駒山系の西側山麓, 大阪と奈 良を結ぶ阪奈道路の袂にある，法人としての歴史は昭和 3 年に始まるが，大学は，今年，開学 20 周年を迎えた ばかり, 若い私立大学である.工, 経営, 経済の 3 学部 と短期大学部を有し，工学部は，土木，交通機械，機械， 電気電子の 4 学科加成る. 大学の学生総数は約 5400 人，土木の学生は約 500 人である. 大学院はない.

\section{土木計画学研究室}

土木計画学研究室は, 楖原 (助教授) が 10 年前に本 学に就任してから創設された。他のスタッフは, 大島 (技 術員), 福井 (同) の 2 名. 共に本学の卒業生である. 卒業研究生として所属する学生は 8 名. 入学者を減らし つつあるのでこの程度であるが，しばらく前までは 2 倍 ほどおり，指導だけで一仕事であった。

是非ともご紹介をしたいのは，コンピュータ関連設備 である、まず，コンピュータは，U-STATION/E 20 と TOSBAC-UX 300 が各 1 台 (OS はともにUNIX), CRT ターミナルが 8 台. パソコンは， 8，16 bit あわせ て 10 台ある。関連機器は, $512 \times 512$ ドット, 1670 万 色同時表示のグラフィック装置（GRAPHICA/M 508）, $X-Y$ プロッタ (A 3 版), ディジタイザ (AO版), ライ ンプリンタなどである.さらに，私学助成を得て，今年 度中にU-STATION がもう 1 台, 1024 ドットのイン テリジェント・グラフィック装置, ドラムスキャナなよ゙ が加わる。

これらは, 他の研究室にも開放し, 卒研生だけでなく, 一般の学生の教育にも最大限利用している. それにして も，計画系の研究室でこれだけの設備を備えるところは 全国でも少ないのではないかとひそかに自負している.

\section{研 究 活 動}

上記のグラフィック装置は, 景観シミュレーション用 に，今年度に購入したものである.したがって，目下の 最大の課題は, そのためのシステム開発である.

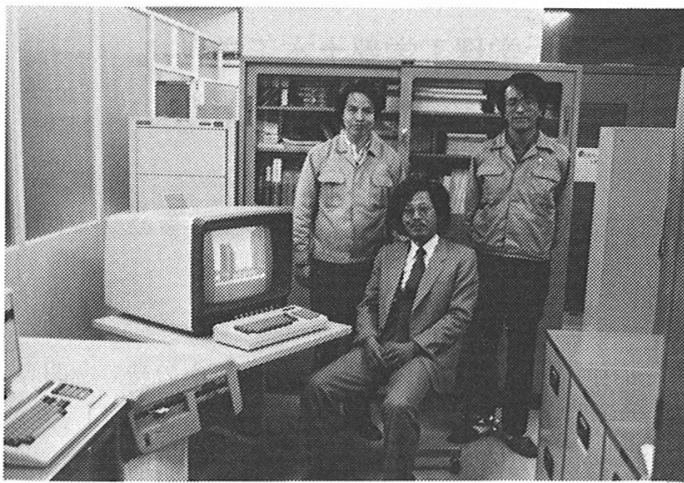

現在ある三次元 CG ソフトは，スキャンラインアル ゴリズムとレイトレーシングのおのおのによるシステム 2 種類で，いずれも GRAPHICA 社のもの.また，新 規購入分には，ローカルZバッファによる隠れ面処理 装置がつくので，主要なアルゴリズムによるソフトは一 応網羅することになる．ところが，景観シミュレーショ ンに用いるには不満なところが多い。たとえば，主に使 用しているスキャンラインアルゴリズムのものでは，平 行光線 (太陽光) ・点光源の処理しかできず，リアルな 陰・影の表現ができない，反射光の処理，透明物体の表 現，テクスチャの表現も不可能である.また，樹木・人 間・地形等の自然物等の表現は, 三次元 CG一般が苦 手とするところで,この問題も解決しなければならない. 早急な実現を目指して取り組んでいるところである.

これまでに行ってきた研究は，第一に，景観工学的研 究である. 街路景観，河川景観，道路横断地下道等を対 象に,主として計量心理学的手法を用いて手掛けてきた。 第二は, 交通計画にかかわる研究で, 最近は, ハンプ・ フォルトの設置効果にかかわる実験的研究等を行ってい る.第三は, パソコンを利用した都市・地域計画支援シ ステムの研究で, 計画情報の図化・データベース・計画 情報解析の各システムの構築を進めてきている.

おわりに

本学のような私立大学では, 昭和 68 年以降の 18 才人 口急減期を控え，存続への危機意識を深めているところ も多い，また，土木工学科は，残念ながら受験生にあま り人気がない，そこで，本土木工学科は，力リキュラム の改正を進め，さらにコース制の採用や大学院の設置を 検討するなど，魅力ある学科づくりを目指している．そ の中でわが土木計画学研究室が果たすべき役割は大きい と思われる. 充実した, 特色ある研究活動を通じて, 学 科, 大学の発展に貢献できればと願っている. 